\title{
BARRIERS TO INCREASE RENEWABLE SHARE IN DOMESTIC ELECTRITY: THE ROLE OF SWITCHING PROVIDER ${ }^{2}$
}

\author{
$\underline{\text { Azucena Gracia }}^{* a b}$, Luis Pérez y Pérez*ab ${ }^{*}$ Jesús Barreiro-Hurlékc \\ ${ }^{a}$ Unidad de Economía Agroalimentaria y de los Recursos Naturales, Centro de Investigación y Tecnología \\ Agroalimentaria de Aragón (CITA). Avda. Montañana 930, 50059, Zaragoza. (agracia@cita-aragon.es, \\ lperez@aragon.es). \\ ${ }^{b}$ Instituto Agroalimentario de Aragón - IA2 (CITA Universidad de Zaragoza), Zaragoza, España. \\ ${ }^{c}$ European Commission. Joint Research Centre (JRC). Sevilla. (jesus.barreiro-hurle@ec.europa.eu).
}

\begin{abstract}
In 2018, electricity represented $23.6 \%$ of final energy use in Spain with a renewable share of $7.2 \%$. With residential electricity consumption representing $30.6 \%$ of electricity use, understanding how households react to increased renewable shares becomes key to reach its objective of $42 \%$ share of renewable in final energy use by 2030 . This paper tries to understand household behaviour with regards to increased renewable share provided by electricity suppliers focusing on whether the increase involves or not changing the utility contract. Thus, we apply a discrete choice experiment delivered to 401 individuals in Aragon in 2020. We estimate an Error Component Random Parameter Logit model with correlated errors to incorporate preference heterogeneity. Our results confirm that households are willing to pay a premium for renewable electricity, however if this implies a change in electricity supplier it does not compensate for the negative WTP associated with that change. Services associated to utility contracts that providers can offer to make the change more attractive do not seem to help overcoming this reluctance to change. Thus, if an increase in renewable electricity for domestic consumption is to be achieved, incumbents should provide it or ease of change to new entrants should be enhanced.
\end{abstract}

Keywords: energy economics, discrete choice experiment, green electricity, household economics, Spain.

\section{Introduction and objectives}

To achieve the goal of being a climate neutral by 2050, the use of renewable energy should be increased. In this context, the Spanish Plan on Energy and Climate established that $42 \%$ of the final use of energy should come from renewable sources by 2030 . Taking into account that residential electricity consumption represents $30.6 \%$ of Spanish electricity use, it is crucial to explore whether households are willing to pay for the increase of renewable sources in their mix. Previous empirical studies have identified that consumers have positive attitudes towards renewable energy and report positive willingness to use and to pay for electricity generated from renewable energy sources. Nevertheless, reported willingness to pay is poorly reflected in actual market shares of renewable electricity (Kaenzig et al. 2013). The reasons for this low use of renewable electricity are diverse and vary according to household' attitudes, personal characteristics and switching costs, among others. The latter is relevant as consumers are reluctant to change providers because changing requires physical effort and involves transaction costs. To better understand the role contract shifting plays in the transition to renewal electricity use, the aim of this paper is to assess the willingness to pay (WTP) for increased renewable presence in the electricity mix in the context of switching contracts or utility company. While there is a growing literature focusing on WTP for green electricity, few of them take into account the switching or choice of electricity supplier (Amador et al. 2013; Kaenzig et al. 2013; Ndebele, 2020). These papers estimate WTP for increased renewable share in domestic electricity using conjoint or choice experiments obtained via switching electricity supplier and considering some additional attributes related to the supplier. We expand the analysis including the possibility of switching contracts but remaining with the same utility company in order to explore the potential role of incumbents and new comers in shaping the new electricity provider landscape in the transition to a carbon neutral power sector.

\section{Methodology}

\subsection{Data}

Data was collected using an online survey implemented by a specialized market research company in February of 2020. The target population are individuals above 18 years of age living in the region of Aragon

\footnotetext{
2 The views expressed are purely those of the authors and may not in any circumstances be regarded as stating an official position of the European Commission.
} 
(north-eastern Spain). This region is considered representative of the Spanish population because its sociodemographic characteristics are similar to the population of Spain. The final sample, stratified by age and gender, includes 401 surveyed households. The questionnaire included questions on attitudes and perceptions towards renewable electricity and asked the intention to use renewable electricity at home and to engage in electricity saving behaviours. Following these questions, the interviewees were faced with a discrete choice experiment. The questionnaire ended with questions to profile the interviewees with regards to their electricity consumption, utility company and socio-demographic characteristics.

\subsection{Choice experiment design}

The first step in designing the choice experiment was to select the attributes and the levels to define the different alternatives. We included three utility contract characteristics and a cost attribute summarized in Table 1 .

Table 1. Electricity attributes and levels

\begin{tabular}{|c|c|c|}
\hline Attribute & Level & Current \\
\hline $\begin{array}{l}\text { Increase in electricity bill } \\
(€ / \text { month })\end{array}$ & $\begin{array}{l}4-8-12-16 \\
\text { COST }\end{array}$ & 0 \\
\hline $\begin{array}{l}\text { Share of renewable electricity } \\
(\%)\end{array}$ & $\begin{array}{l}20-30-40-50 \\
\text { RENEWABLE }\end{array}$ & $10 \%$ \\
\hline Change electricity contract & $\begin{array}{l}\text { Yes, with the same company } \\
\text { SAME_COMPANY } \\
\text { Yes, with other company }\end{array}$ & $\begin{array}{l}\text { No changing } \\
\text { contract }\end{array}$ \\
\hline $\begin{array}{l}\text { Value added services in new } \\
\text { contract }\end{array}$ & $\begin{array}{l}\text { Free coupon to buy an } \mathrm{A}^{+++} \text {electricity device }(50 €) \\
\text { SERVICES } \\
\text { Free coupon to buy an } \mathrm{A}^{+++} \text {electricity device }(50 €) \\
+ \text { Free electricity audit }\end{array}$ & $\begin{array}{l}\text { No free coupon } \\
\text { and/or } \\
\text { electricity audit }\end{array}$ \\
\hline
\end{tabular}

The choice tasks were generated following the Hole (2016) approach with STATA 14.0. The design to estimate the main effects with four attributes with 4, 4, 2, and 2 levels generated 24 choice tasks. They were randomly split into four blocks and each respondent had to make six choices. Each choice set included three alternatives: two designed and the current situation (statu quo).

\subsection{Model specification and estimation}

The utility function is derived from the Lancaster theory as a function of the products attributes and unobservable components assumed stochastic (random utility theory). In the empirical application and for the selected attributes and levels, the utility function specified for individual $n$, alternative $j$ at choice situation $t$, is as follows:

$$
\mathrm{U}_{\mathrm{njt}}=\mathrm{SQ} A \mathrm{Asc}+\beta_{1} \operatorname{COST}_{\mathrm{njt}}+\beta_{2} \text { RENEWABLE }_{\mathrm{njt}}+\beta_{3} \text { SAME_COMPANY }_{\mathrm{njt}}+\beta_{4} \text { SERVICES }_{\mathrm{njt}}+\varepsilon_{\mathrm{njt}}
$$

where, $n$ is the number of respondents, $j$ represents the alternatives in the choice sets (A, B and the Statu $q u o$ ) and $t$ the number of sets. The betas are parameters to be estimated. SQ_Asc is the alternative specific constant for the Statu quo option. The payment vehicle (COST) and the percentage of renewable electricity (RENEWABLE) were defined by the levels in the design. The attributes of switching electricity contract (SAME_COMPANY) and additional services (SERVICES) were included as effect coded variables $(+1$ for the same company/free coupon, -1 for the other company/free coupon plus free audit and, 0 otherwise). Heterogeneity in consumers' preferences was assumed and an Error Component Random Parameters Logit model (ECRPL) with correlated errors was estimated using the NLOGIT 6.0.

\section{Results}

The final sample was representative of the Aragonese and Spanish population in terms of gender and age. Equation 1 was estimated assuming that the payment vehicle (COST) is a fixed coefficient and that the coefficients for the attribute-levels variables are random following a normal distribution (Table 2). The coefficients for SQ_Asc and COST were negative and statistically significant as expected. The negative sign of the SQ_Asc variable shows that households prefer the alternatives offered to their current contract (no change in cost, $10 \%$ of renewables in the mix and no additional services).

Table 2. Estimates for the Error Component Random Parameters Logit model with correlated 


\begin{tabular}{|c|c|c|c|c|}
\hline Attributes & $\begin{array}{c}\text { Mean } \\
\text { Estimation }\end{array}$ & $\begin{array}{c}\text { Standard } \\
\text { deviation of } \\
\text { coefficient }\end{array}$ & WTP & $\% \mathrm{WTP}>0$ \\
\hline SQ_Asc & $\begin{array}{c}-2.150 * * * \\
(-6.74)\end{array}$ & --- & --- & --- \\
\hline COST & $\begin{array}{c}-0.178 * * * \\
(-17.87)\end{array}$ & --- & --- & --- \\
\hline RENEWABLE & $\begin{array}{c}0.037 * * * \\
(5.58)\end{array}$ & $\begin{array}{c}0.077 * * * \\
(9.93)\end{array}$ & $\begin{array}{c}0.42 * * * \\
(5.66)\end{array}$ & 71 \\
\hline SAME_COMPANY & $\begin{array}{c}0.117 * * * \\
(2.64)\end{array}$ & $\begin{array}{c}0.402 * * * \\
(6.14)\end{array}$ & $\begin{array}{c}1.31 * * * \\
(2.66)\end{array}$ & 72 \\
\hline SERVICES & $\begin{array}{l}-0.027 \\
(0.70)\end{array}$ & $\begin{array}{c}0.234 * * * \\
(2.43)\end{array}$ & $\begin{array}{l}\text { ns } \\
\text { ns }\end{array}$ & \\
\hline$\sigma$ & $\begin{array}{c}4.85 * * * \\
(11.72)\end{array}$ & & & \\
\hline
\end{tabular}

Number of observations: 2406; Log likelihood: -1727.04; McFadden Pseudo R-square: 0.32

$* * *=$ significance at $1 \%$; ns: not statistically significant

The estimated coefficient for the RENEWABLE variable was positive and statistically significant indicating that higher percentage of renewable origin in the electricity mix increases the consumers' utility. In addition, the positive and statistically significant value of the parameter estimate SAME_COMPANY indicated that the utility for switching the contract but keeping the same company was higher than the utility of switching the contract to other company. Finally, receiving some added services for switching the contract (SERVICES) was not valued by households because the estimated parameter was not statistically significant. The estimated coefficients for the standard deviation were positive and statistically significant at $1 \%$ level corroborating that consumers' preferences for these attributes were heterogeneous. Thus, in the last column in table 3 the percentage of individuals willing to pay for renewable electricity and to switch the electricity contract with the same company in relation to other company is shown. The $71 \%$ of respondents were willing to pay a positive premium for higher percentage of renewable electricity and the $72 \%$ of households were willing to switch their electricity contract but keeping the same electricity company.

Additionally, and following Train (2003), estimated parameters have been used to simulate market shares for different utility contracts. With the overall target of maximizing renewable share in the market, we consider three potential markets. In all markets, we include the SQ contract type and assess strategies by both the incumbent and new entrants. Strategy one considers the incumbent offers increasing shares of renewables at increasing costs. Strategy two considers higher shares of renewables are only offered by new entrants at higher cost. Last, strategy three sees the incumbent offering high shares of renewables at high cost and the new entrant focusing on low prices and low increases of renewables but offering associated services (Table 3).

Table 3. Simulated market shares for different contracts under alternative market structures

\begin{tabular}{|c|c|c|c|c|c|c|}
\hline Company & $\begin{array}{c}\text { Renewable } \\
\text { share }\end{array}$ & $\begin{array}{c}\text { Price } \\
\text { increase }\end{array}$ & Associated services & Market 1 & Market 2 & Market 3 \\
\hline Incumbent & 10 & 0 & None & 9.4 & 8.8 & 9.9 \\
\hline Incumbent & 20 & 4 & None & 34.1 & & \\
\hline Incumbent & 30 & 8 & None & 19.8 & & \\
\hline Incumbent & 40 & 12 & None & 16.6 & & \\
\hline Incumbent & 50 & 16 & None & 20.0 & & \\
\hline Incumbent & 20 & 4 & None & & 35.2 & \\
\hline Incumbent & 30 & 8 & None & & 21.6 & \\
\hline New entrant & 40 & 12 & None & & 15.6 & \\
\hline New entrant & 50 & 16 & None & & 18.8 & \\
\hline Incumbent & 40 & 12 & None & & & 18.8 \\
\hline Incumbent & 50 & 16 & None & & & 21.4 \\
\hline New entrant & 20 & 4 & coupon + electricity audit & & & 31.4 \\
\hline New entrant & 30 & 8 & coupon + electricity audit & & & 18.5 \\
\hline
\end{tabular}

As it can be seen, there is a strong preference for shifting contracts to higher renewable shares. The most successful contracts are driven mainly by price (maximum market shares are always bounded to the lowest 
price increase). New entrants, capture more than $50 \%$ of the market in the simulated market 3, therefore it seems that a strategy to capture market could focus on low increases in renewables at a low cost.

Table 4 reports the average renewable share in the contracts assuming a homogenous distribution of consumption across households and the average increase in the monthly electricity bill.

Table 4. Estimated average renewable share

\begin{tabular}{lccc}
\hline & Market 1 & Market 2 & Market 3 \\
\hline Renewable share (\%) & 30.34 & 30.04 & 31.04 \\
Average increased cost (€/month) & 8.14 & 8.01 & 8.42 \\
\hline
\end{tabular}

The increase of renewable share in total consumption in all markets is significant tripling the current renewable share from $10 \%$ to $30 \%$, irrespective of the market strategies of both incumbent and new entrants. Households are willing to pay $8 €$ more in their monthly bills to promote this transition.

\section{References}

Amador, F.J., González, R.M. y Ramos-Real, F.J. (2013). "Supplier choice and WTP for electricity attributes in an emerging market: The role of perceived past experience, environmental concern and energy saving behaviour". Energy Economics, 40:953-966.

Hole, R. (2016). Creating efficient designs for discrete choice experiments with STATA. Accesible at: https://www.stata.com/meeting/nordic-and-baltic16/slides/norway16_hole.pdf

Kaenzig, J., Heinzle, S. L. y Wüstenhagen, R. (2013). "Whatever the customer wants, the customer gets? Exploring the gap between consumer preferences and default electricity products in Germany". Energy Policy, 53:311-322.

Ndebele, T. (2020). "Assessing the potential for consumer-driven renewable energy development in deregulated electricity markets dominated by renewables". Energy Policy, 136:111057.

Train, K. (2003). Discrete Choice Methods with Simulation. Cambridge Univ. Press, Cambridge. 